\title{
Factors Associated With Contraceptive Use In Reproductive Age Couples
}

\author{
Desak Nyoman Suryaningrat ${ }^{1}$, Ni Wayan Suniyadewi ${ }^{2}$,Ni Luh Putu Dewi Puspawati ${ }^{3}$ \\ 'Bali Mandara Hospital, Jl. By Pass, Ngurah Rai No 548, Sanur, Denpasar, Bali \\ ${ }^{2,3}$ Stikes Wira Medika Bali, Jl. Kecak No 9A Gatot Subroto Timur, Denpasar, Bali \\ Email: suniyadewi0285@gmail.com
}

\begin{abstract}
Abstrak
Ibu adalah anggota keluarga yang berperan penting. Saatinikematian ibu yang terjadi dalam setiap menit di setiap harinya sebagian besar disebabkan oleh komplikasi yang berhubungan dengan kehamilan, persalinan, dan nifas. Penggunaan alat kontrasepsi pada pasangan usia subur merupakan salah satu strategi dari program KB untuk mengurangi kematian ibu. Tujuan penelitian ini adalah untuk mengetahui faktor-faktor yang berhubungan dengan penggunaan alat kontrasepsi pada pasangan usia subur. Penelitian ini menggunakan desain korelasi dengan pendekatan cross-sectional. Sampel dalam penelitian ini dipilih dengan teknik non probality sampling yaitu purposive sampling sebanyak 56 orang. Analisa data dilakukan menggunakan uji Rank Spearman dan uji koefisien contingensi. Hasil penelitian menunjukan bahwa ada hubungan antara penggunaan alat kontrasepsi dengan faktor umur, pendidikan, pekerjaan, adat istiadat/budaya dan kualitas pelayanan $K B$ dengan nilai $p<0,05$. Berdasarkan hasil penelitian, disarankan kepada UPT Puskesmas I Mengwi agar menyiapkan ruangan konseling bagi akseptor KB dan meningkatkan jadwal pelayanan KB serta meningkatkan kualitas tenaga kesehatan terutama dalam memberikan konseling alat kontrasepsi.
\end{abstract}

Kata kunci: Pasangan Usia Subur, Penggunaan alat kontrasepsi

\section{Abstract}

Mothers are family members who play an important role in family life. Maternal deaths that occur in every minute at every day are mostly caused by complications related to pregnancy, childbirth, and puerperal. Contraceptive use in reproductive-age couples is one of the strategies of family planning to reduce maternal mortality. This study aimed to investigate the factors associated with contraceptive use in reproductive age couples. This study used a correlational design with a cross-sectional approach. The samples were 56 people selected using a nonprobability sampling technique, i.e., purposive sampling. Data were analyzed using Rank Spearman test and contingency coefficient test. The results showed that there was a correlation between contraceptive use and factors of age, education, employment, customs/culture and quality of family planning services with a $p$-value of $<0.05$. This study recommends that Mengwi Public Health Center I provide a counseling room for family planning acceptors and increase the schedule of family planning services as well as improve the quality of health workers especially in giving counseling about contraceptive use.

Keywords: Reproductive Age Couples, Contraceptive Use 
Info Artikel:

Artikel dikirim pada 01 November 2018

Artikel direvisi pada 05 Januari 2019

Artikel diterima pada 20 Februari 2019

DOI: http://dx.doi.org/10.21927/jnki.2019.7(1).47-53

\section{INTRODUCTION}

Mothers are family members who play an important role in managing all household chores. Of all members of the family, mothers are the ones to receive priority. Special attention on efforts made to improve maternal health is also required. Furthermore, it is necessary to monitor the assessment of health status and performance of mothers, as maternal mortality rate (MMR) becomes an important indicator in describing the welfare of the community in a country (1).

World Health Organization (WHO) reported that maternal mortality was estimated to be 216 per 100,000 births in 2015. Data from the Indonesian Demographic and Health Survey(IDHS) from 1991 to 2007 showed that the maternal mortality rate decreased from 390 to 228 per 100,000 live births. However, in 2012, the IDHS found that the maternal mortality rate returned to 359 per 100,000 live births. The results of IDHS in 1990 and 2012 regarding MMR were not much different. However, it was predicted that it would be quite difficult to reach the target of 102 MMR in 2015. This statistic is also further away from the 2015 MDG target of 102 per 100,000 live births and SDGs target by 2030, reduce the global maternal mortality ratio to less than 70 per 100,000 live births (2).

One of the alternative ways to deal with the high maternal mortality rate is to delay pregnancy; one of which is through the use of contraception. Contraceptive use in reproductive-age couples is one of the strategies of the family planning program to reduce maternal mortality with $4 T$ conditions: too young to give birth (under the age of 20 years), too often to give birth, too close birth spacing, and too old to give birth (over the age of 35 years) (3).

The government has made some efforts to overcome the low coverage of family planning for reproductive-age couples. However, the results are not yet satisfactory. The rate of participation in family planning for reproductive couples is still low. Some factors that influence this low participation include the low level of knowledge about family planning, socio-cultural, and socioeconomic aspects of the community, and the access to family planning services. Previous studies reported that knowledge, culture, and access to family planning services were factors that significantly affected the participation of reproductive age men in choosing male methods of contraception.

This study aimed to determine the factors associated with the use of contraception in reproductive age couples, including age, education, work, customs/culture and the quality of family planning services.

\section{MATERIALS AND METHODS}

This study employed a correlational research design, focusing on knowing the correlation that occurs in a particular phenomenon. The independent variables in this study are age, education, work, customs/culture and the quality of family planning services and dependent variables is contraceptive use in reproductive age couples. This study used a cross-sectional approach, in which measurements or observations at the same time (one-time observation) between risk factors or exposure to disease were carried out (4). This study was conducted at the mother and child clinic in Mengwi Public Health Center I in Bali from May 18 to June 9,2018 . The population was all reproductive-age couples undergoing an examination at the family planning polyclinic at the related public health center. In the last three months, the total number of reproductive age couple visiting the clinic was 191 , with an average of 64 per month. The samples in this study were recruited using a nonprobability sampling technique, i.e., purposive sampling.

The number of samples in this study was 56 people. The instrument that has been used in this study is a questionnaire about age, education, 
work, customs/culture, the quality of family planning services and contraceptive use in reproductive age couples. The Rank Spearman test was used to analyze the correlation between variables in unpaired groups that are abnormally distributed with ordinal data. The contingency coefficient test was also used to test the hypothesis with nominal and ordinal forms of data (5).

\section{RESULTS AND DISCUSSION}

Results of observations on factors associated with contraceptive use in reproductive-age couples are presented below.

Table 1. Age of Reproductive Couples

\begin{tabular}{lll}
\hline Age Group & $\mathrm{f}$ & $\%$ \\
\hline Early adolescence (12-16 years) & 8 & 14.3 \\
Late adolescence (17-25 years) & 26 & 46.4 \\
\hline Early adulthood (26-35 years) & 22 & 39.3 \\
\hline Total & 56 & 100.0 \\
\hline
\end{tabular}

Based on Table 1, it is shown that most respondents were in the late adolescence with the age of $17-25$ years as many as 26 people (46.4\%).

Table 2. Education of Reproductive Age Couples

\begin{tabular}{lll}
\hline Education & $\mathrm{f}$ & $\%$ \\
\hline Primary education & 3 & 5.4 \\
\hline Secondary education & 27 & 48.2 \\
\hline Higher education & 26 & 46.4 \\
\hline Total & 56 & 100.0
\end{tabular}

Based on Table 2, it can be seen that most respondents had secondary education as many as 27 people $(48.2 \%)$.
Table 3. Employment of Reproductive Age Couples

\begin{tabular}{lll}
\hline Employment & $\mathrm{f}$ & $\%$ \\
\hline Civil Servants & 10 & 17.9 \\
\hline Police/Soldiers & 18 & 32.1 \\
\hline Private Employees & 28 & 50.0 \\
\hline Total & 56 & 100.0
\end{tabular}

Based on Table 3, it is shown that most of the respondents worked as private employees amounted to 28 people (32.1\%).

Table 4. Customs/Cultures of Reproductive Age Couples

\begin{tabular}{lll}
\hline Customs/Cultures & $\mathrm{f}$ & $\%$ \\
\hline Affecting & 26 & 46.4 \\
\hline Not Affecting & 30 & 53.6 \\
\hline Total & 56 & 100.0
\end{tabular}

Based on Table 4, it was found that most respondents as many as 30 (53.3\%)had customs/ cultures that did not affect their contraceptive use.

Table 5. Quality of Family Planning Service

\begin{tabular}{lcc}
\hline Quality of family planning service & $\mathrm{f}$ & $\%$ \\
\hline Good & 26 & 46.4 \\
\hline Sufficient & 22 & 39.3 \\
\hline Insufficient & 8 & 14.3 \\
\hline Total & 56 & 100 \\
\hline
\end{tabular}

Based on Table 5, it was indicated that the majority of respondents, amounted to 26 people (46.4\%), reported good quality of family planning services. 
Table 6. Use of contraceptive devices

\begin{tabular}{lll}
\hline Contraceptive Use & f & $\%$ \\
\hline Using contraceptive devices & 24 & 42.9
\end{tabular}

Not using contraceptive devices 3257.1

\begin{tabular}{lr}
\hline Total & 56100.0
\end{tabular}

Based on Table 6, it can be seen that the majority of respondents as many as 32 people $(57.1 \%)$ did not use contraceptive devices.

Table 7. Correlation between Age and Contraceptive Use

\begin{tabular}{|c|c|c|c|c|c|c|c|c|}
\hline \multirow[b]{3}{*}{ Age (Years old) } & \multicolumn{6}{|c|}{ Used Contraception } & \multicolumn{2}{|c|}{ Spearman's Rho } \\
\hline & \multicolumn{2}{|c|}{ Used } & \multicolumn{4}{|c|}{ Not Used Total } & & \\
\hline & $f$ & $\%$ & $f$ & $\%$ & $f$ & $\%$ & $r$ & Sign (2-tailed) \\
\hline $12-16$ & 0 & 0 & 8 & 14.2 & 8 & 14.2 & \multirow{4}{*}{-0.35} & \multirow{4}{*}{0.008} \\
\hline $17-25$ & 11 & 19.6 & 15 & 26.7 & 26 & 46.5 & & \\
\hline $26-35$ & 13 & 23.4 & 9 & 16.1 & 22 & 39.3 & & \\
\hline total & 24 & 43 & 32 & 57 & 56 & 100 & & \\
\hline
\end{tabular}

Table 7 shows that most respondents who were at late adolescence age (17-25 years old) as many as $15(46.9 \%)$ did not use any contraception. The results of the statistical test showed a sig. (2-tailed) value of 0.008 and the correlation coefficient was positive with a value of 0.351 . The value of sig. (2-tailed) was $0.008<0.05$, indicating that the hypothesis was accepted. Thus, there was a significant correlation between age and the use of contraception. The positive correlation coefficient indicated that the increasing age of reproductive-age couples increased the use of contraception with a value of 0.351 , meaning that the relationship between the two variables was weak (0.21-0.40).

Table 8. Correlation between Education and Contraceptive Use

\begin{tabular}{|c|c|c|c|c|c|c|c|c|}
\hline \multirow{3}{*}{ Education } & \multicolumn{6}{|c|}{ Used Contraception } & \multirow{2}{*}{\multicolumn{2}{|c|}{ Spearman's Rho }} \\
\hline & \multicolumn{2}{|c|}{ Used } & \multicolumn{2}{|c|}{ Not Used } & \multicolumn{2}{|c|}{ Total } & & \\
\hline & $f$ & $\%$ & $f$ & $\%$ & $f$ & $\%$ & $r$ & Sign (2-tailed) \\
\hline Primary & 2 & 3.6 & 19 & 33.9 & 21 & 37.5 & & \\
\hline High School & 15 & 26.7 & 12 & 21.4 & 27 & 48.2 & 303 & 0,023 \\
\hline College & 7 & 12.6 & 1 & 1.79 & 8 & 14.3 & 303 & 0.023 \\
\hline Total & 24 & 42.9 & 32 & 57.1 & 56 & 100 & & \\
\hline
\end{tabular}

Table 8 shows that the majority of respondents with primary education as many as 19 people (54.9\%) did not use contraception. The results of the statistical tests showed a sig. (2tailed) value of 0.023 and the correlation coefficient was positive with a value of 0.303 . The Sig. (2-tailed) value was $0.023<0.05$, meaning that the hypothesis was accepted. Hence, there was a significant correlation between education and the use of contraception. The positive correlation coefficient means that the lower the education of reproductive age couples, the lower the use of contraception was with a value of 0.303 , indicating the relationship of the two variables was weak (0.21-0.40).

Table 9. Correlation between Employment and the Use of Contraception

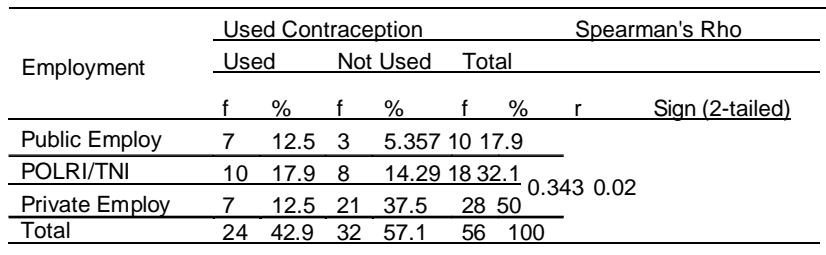

Table 9 shows that most respondents working as private employees as many as 21 , did not use contraception as evident. The value of Sig (2-tailed) value was $0.02<0.05$, indicating that the hypothesis was accepted with a contingency coefficient of 0.020 . Thus, there was a significant correlation between employment and contraceptive use among reproductive-age couples.

Table 10. Correlation between Customs/Cultures and the Use of Contraception

\begin{tabular}{|c|c|c|c|c|c|c|c|c|}
\hline \multirow{3}{*}{$\begin{array}{l}\text { Customs/ } \\
\text { Culture }\end{array}$} & \multicolumn{6}{|c|}{ Used Contraception } & \multicolumn{2}{|c|}{ Spearman's Rho } \\
\hline & \multicolumn{2}{|c|}{ Used } & \multicolumn{2}{|c|}{ Not Used } & \multicolumn{2}{|c|}{ Total } & & \\
\hline & $f$ & $\%$ & $f$ & $\%$ & $f$ & $\%$ & $r$ & Sign (2-tailed) \\
\hline Related & 1 & 1.79 & 9 & 16.07 & 10 & 17.9 & & \\
\hline Unrelated & $\begin{array}{l}2 \\
3 \\
\end{array}$ & 41.1 & 23 & 41.07 & 46 & 82.1 & 0.343 & 0.021 \\
\hline Total & $\begin{array}{l}2 \\
4\end{array}$ & 42.9 & 32 & 57.1 & 56 & 100 & & \\
\hline
\end{tabular}

Table 10 shows that most respondents who were not influenced by customs/cultures. The Sig. (2-tailed) value was $0.020(<0.05)$, indicating that the hypothesis was accepted with correlation coefficient 0.343 . Thus, there was a significant correlation between Customs/Cultures and contraceptive use. 
Table 11. Correlation between Quality of Family Planning Services and the Use of Contraception

\begin{tabular}{|c|c|c|c|c|c|c|c|}
\hline \multirow{3}{*}{$\begin{array}{l}\text { Service } \\
\text { quality }\end{array}$} & \multicolumn{5}{|c|}{ Use Contraception } & \multirow{2}{*}{\multicolumn{2}{|c|}{ Spearman's Rho }} \\
\hline & \multicolumn{2}{|c|}{ Used } & \multicolumn{2}{|c|}{ Not Used } & Total & & \\
\hline & $f$ & $\%$ & $f$ & $\%$ & $\%$ & $r$ & Sign(2-tailed) \\
\hline Good & 14 & 25 & 8 & \multicolumn{2}{|c|}{14.292239 .3} & & \\
\hline Fair & \multicolumn{5}{|c|}{1017.91221 .432239 .3} & & \\
\hline Poor & 0 & 0 & & 21.431 & 21.4 & & \\
\hline Total & 24 & 42.9 & 32 & 57.1 & $56 \quad 10$ & & \\
\hline
\end{tabular}

Table 11 shows that most respondents who did not use contraception reported that the qualities of family planning services were sufficient and insufficient with a sig. (2-tailed) value of 0.028 and a positive correlation coefficient of 0.293 . The Sig value (2-tailed) was $0.028(<0.05)$, meaning that the hypothesis was accepted. Hence, there was a significant correlation between the quality of family planning services and the use of contraception. A positive correlation coefficient meant that the higher the quality of family planning services, the higher the use of contraceptives in reproductive age couple was with a value of 0.293 . This indicated the correlation between the two variables was weak (0.21-0.40).

\section{Correlation between Age and the Use of Contraceptive Methods}

The statistic test showed sig. (2-tailed) value of 0.008 with a positive correlation. This result indicated a significant correlation between age and contraceptive use. The older the age, the better the use of contraceptives was. The results of this study are in accordance witha study which states that there was a correlation between the age of the mother and the selection of long-term contraceptive methods with a ñ-value of 0.040 ; the $p$-value was smaller than the á-value of 0.05 (6).

The reproductive age couples over 35 years old are recommended to use the effective nonhormonal contraceptive methods. So it can be concluded that age has a positive correlation with the choice of contraceptive method, in which along with the high maturity or age of respondents, there would be increased knowledge in the selection of nonhormonal contraceptive methods (7).

The increasing age of an individual will cause some changes in physical and psychological aspects. Physical growth occurs due to the maturation of organ function. In terms of the psychological aspect or level of thinking, the increased age will make an individual more matured (8). The higher a person's age, the more mature the level of thinking and strength of a

person will be. As an intrinsic factor, age has a relationship with the use of contraceptive methods. Age is related to organ structure, physiological function, and biochemical composition including the hormonal system of female respondents (9). Differences in physiological function, biochemical composition, and hormonal system in the age will cause differences in the needs of contraception. The older a person is, the choice of contraceptive devices is more on a tool that has higher effectiveness, i.e., the long-term contraceptive methods.

\section{Correlation between Education and the Use of Contraceptive Methods}

This study showed a sig. (2-tailed) value of $0.023<0.05$, meaning that there was a significant correlation between education and the use of contraception. The positive correlation coefficient means that the lower the education of reproductive age couples, the lower the use of contraceptives was. The results of this study are in line with a previous study reporting that there was a relationship between the level of education, the use of contraception and the number of born children. The correlation was very strong with the value of Qxy Tied T of 0.84 (9).

Based on the theory, formal education has a very significant influence on an individual's knowledge. If someone is highly educated, then he/she will have high knowledge. In contrast, if someone has low education, he/she will have low knowledge that influences his/herunderstanding of something (12). The educational process lasts a lifetime or until a person dies. The life-long education concept describes all events of someone's teaching and learning activities. Before undergoing formal education at school, any individuals will first get an informal education in the family, and if possible, they can continue to college education (10). The study also mentions that couples of childbearing age with the higher education have 5,9 times higher to have an opportunity to use the IUD contraception, after 
controlling for the variable of husband support, as well as age, parity becomes confounding variables (11).

\section{Correlation between Employment and the Use of Contraceptive Methods}

This study showed a correlation between employment and the use of contraceptive methods with a contingency coefficient value of 0.020 . The contingency coefficient value was $0.020<0.05$, meaning that the correlation was significant. This result is congruent with a study reporting a relationship between the employment of mothers and the selection of contraceptive injection $(p=0.031$, or $=4.455)(12)$.

Statistically, there is a significant correlation between the employment associated with the level of income and the use of contraception. Many couples believe that to determine the use of contraceptive methods, they should consider their financial ability to buy the contraceptives so that the use of such contraceptives will not be burdensome for the users (13).

According to researchers, the status of employment is very related to the income or economic conditions of reproductive age couples. Good employment and knowledge will provide ease for the couples to access or to buy contraceptives following the advice of health workers such as doctors or midwives.

\section{Correlation between Customs /Cultures and the Use of Contraceptive Methods}

This study showed a correlation between the customs/cultures and the use of contraceptive methods. The contingency coefficient value was $0.020<0.05$, meaning that the correlation was significant.

The result of this study is in line with a study reporting that there was a relationship between cultural factors and the use of intrauterine contraceptives with $p$-value $=0.0005$. As a social being, humans cannot be separated from cultures. They will be influenced by the cultures in which they live. Cultures involve customs, traditions, habits, rules, and opinions. The use of contraceptive methods is also influenced by the cultures considering that the users also live in a cultural environment (14). (15) is also mentions that, there is a relationship between beliefs and the choice of contraception.

\section{Correlation between Quality of Family Planning Services and the Use of Contraceptive Methods}

This study showed a correlation between the quality of family planning service and the use of contraceptive methods. The contingency coefficient value was $0.028<0.05$, meaning that the correlation was significant.

The result of this study is supported by a previous study which reported a relationship between the quality of family planning services provided by midwives and the selection of longterm contraceptive methods with a $p$-value of $<0.05$ (13)

There are many factors which influence any individuals in choosing their contraceptive methods. In addition to the individual factors (sociodemographic characteristics), there are also environmental factors (family, community), and program factors related to increasing knowledge and quality of services, as well as facilities (availability of contraceptive drugs, health workers, services, and costs) that affect an individual to choose contraceptive methods (13).

To choose the appropriate contraceptive method, clients should have sufficient knowledge which can be obtained from the professional health workers, for example, and an understanding of the contraception that will be used. One way to increase the quality of family planning services is to provide options of complete and clear methods of contraception that are rational, safe and effective. Thus, clients can have more flexibility to decide the contraceptive methods that they will use. If a midwife provides an overview of the advantages and disadvantages of all contraceptive methods, the midwife can help the clients make the choice of the appropriate contraceptive method based on the information provided (16). 


\section{CONCLUSION AND RECOMMENDATION}

There was a correlation between the factors of age, education, employment, customs/ cultures, and quality factors of family planning services, and the use of contraceptive methods in reproductive age couples with a $p$-value of $<0.05$.

Reproductive age couples are expected to be more proactive in obtaining specific information about family planning contraceptive services.

The health office should promote family planning counseling and the importance of using contraceptive methods for reproductive age couples so that they will know more aboutfamily planning counseling services available at the public health centers. As a result, couples will be more motivated to use contraceptive devices.

Further research can be conducted by considering the use of multifactorial analysis, such as examining the factors that influence the type of contraception in reproductive age couples.

\section{REFERENCES}

1. KEMENKES. infodatin. Pusat Data dan Informasi Kemenkes RI. 2014;

2. Nursalam. Konsep dan Penerapan Metodologi Penelitian IImu Keperawatan. Salemba Med. 2008;

3. Rahmawati. Faktor-Faktor Yang Mempengaruhi Partisipasi Pria Pasangan Usia Subur (PUS) Dalam Memilih Metode Kontrasepsi Pria di Desa PauhT imur Wilayah Kerja Puskesmas Kota Pariaman. 2015;

4. Sitronela. Hubungan Usia Dan Paritas Dengan Penggunaan Metode Kontrasepsi Jangka Panjang Pada Akseptor Baru Di Puskesmas Lendah 1 Kulon Progo Yogyakarta. 2017;

5. Saifuddin. IImu Kebidanan Sarwono Prawirohardjo, Edisi 4. Jakarta: PT Bina Pustaka Sarwono Prawirohardjo. 2009;

6. Mubarak WI, Chayatim N, Rozikin Kh, Supradi. Promosi Kesehatan Sebuah Pengantar Proses Belajar Mengajar dalam Pendidikan Yogyakarta. Graha IImu. 2007;

7. Wawan, A dan Dewi M. Teori dan Pengukuran Pengetahuan, Sikap dan Perilaku Manusia. Syafni. 2012;
8. Lestiani, Ika. Determinant of Intrauterine Contraception (IUD) Election on Couples of Childbearing Age. 2017; Available: https:// ejournal.almaata.ac.id/index.php/JNKI/ article/view/545/pdf.

9. Yulidasari. Hubungan Pengetahuan Ibu Dan Pekerjaan lbu Dengan Pemilihan Kontrasepsi Suntik. 2015; Available (online): https://media.neliti.com/media/publications/ 255969-hubungan-pengetahuan-ibu-danpekerjaan-i-bd73d5c5.pdf

10. Setyowati T. Faktor-Faktor Yang Berhubungan Dengan Penggunaan Alat Kontrasepsi Dalam Rahim Pada Akseptor KB Golongan Resiko Tinggi Di Puskesmas Wilayah Kec. Cimahi Selatan Kota Cimahi Tahun 2008. J Kesehat Stikes Kartika Ahmad Yani. 2010;

11. Aritonang. Hubungan Budaya Patriarki terhadap Keputusan WUS Menjadi Akseptor Keluarga Berencana di Lingkungan VI Simpang Selayang Medan Tuntungan Tahun 2010. Sumatera: Universitas Sumatera Utara. 2010;

12. Dyah Pratiwi E, Sariyati S. Agama dengan Keikutsertaan Keluarga Berencana (KB) dan Pemilihan Jenis Alat Kontrasepsi pada Pasangan Usia Subur (PUS) di Desa Argomulyo Sedayu Bantul Yogyakarta. J Ners dan Kebidanan Indones. 2016;

13. BKKBN. Rencana Strategis Badan Kependudukan Dan Keluarga Berencana Nasional. Bkkbn. 2015; 